\title{
Mud, muddle and models in the knowledge value-chain to action on tropical peatland conservation
}

\author{
Meine van Noordwijk • Robin Matthews • Fahmuddin Agus • Jenny Farmer • \\ Louis Verchot • Kristell Hergoualc'h • Sebastian Persch • Hesti Lestari Tata • \\ Betha Lusiana • Atiek Widayati • Sonya Dewi
}

Received: 4 March 2014 / Accepted: 15 May 2014 / Published online: 19 June 2014

(C) The Author(s) 2014. This article is published with open access at Springerlink.com

\begin{abstract}
Tropical peatlands are known not only for their high, area-based, carbon emissions in response to land-use change but also as hot spots of debate about associated data uncertainties. Perspectives are still evolving on factors underlying the variability and uncertainty. Debate includes the ways of reducing emissions through rewetting, reforestation and agroforestry. A knowledge value-chain that is long and complex links (a) fundamental understanding of peat and peatland processes leading to sciencebased quantification and default values, (b) willingness and (c) ability to act towards emission reduction, and ultimately (d) to local, national and global actions that effectively provide rules, incentives and motivation to conserve peat and reduce emissions. We discuss this value chain, its stakeholders and issues that still remain partially unresolved. We conclude that, to shorten the denial and conspiracy-theory stages of debate that otherwise slow down steps B and C, networks of international and national scientists have to be involved at the early stage of identifying policysensitive environmental issues. Models span part of the knowledge value-chain but transition of analysis units requires specific attention, from soil volumes through area and commodity flows to
\end{abstract}

M. van Noordwijk $\cdot$ H. L. Tata $\cdot$ B. Lusiana $(\bowtie) \cdot$ A. Widayati $\cdot$ S. Dewi

World Agroforestry Centre (ICRAF), P O Box 161, Bogor 16001, Indonesia

e-mail: b.lusiana@cgiar.org

M. van Noordwijk

e-mail: m.vannoordwijk@cgiar.org

R. Matthews

James Hutton Institute, Craigiebuckler, Aberdeen AB15 8QH, UK

F. Agus

Indonesian Soil Research Institute, Bogor, Indonesia

J. Farmer

University of Aberdeen, Aberdeen, UK

L. Verchot $\cdot$ K. Hergoualc'h $\cdot$ S. Persch

Center for International Forestry Research (CIFOR), P O Box 113, Bogor 16000, Indonesia

H. L. Tata

Forestry Research and Development Agency (FORDA), Jl. Gunung Batu No. 5, Bogor, Indonesia 
opportunities for reductions. While drainage of peatlands triggers landscape-scale increases in emissions, factors beyond drainage depth, including nutrient supply, may have a major influence on decomposition rates. Attempts to disentangle the contributions of plant and peat-based respiration in surface flux measurements involve assumptions that cannot be easily verified in comparisons between land uses. With progress on A leading to new internationally accepted defaults and with resistance on step B reduced, the reality of $\mathrm{C}$ and lack of working solutions for $\mathrm{D}$ is currently constraining further progress.

Keywords Boundary work · Carbon emission · Credibility - Indonesia · Land use · Legitimacy · Salience $\cdot$ Science-policy interface $\cdot$ Simulation model

\section{Introduction}

Tropical peatlands have become hot spots of greenhouse gas emissions, with much debate about their quantification and efforts to reduce them (e.g. Hooijer et al., 2012; Hergoualc'h and Verchot, 2013; IPCC, 2014). Emission estimates from tropical peatlands converted from their wet natural forest condition to a drier form of human land use are large numbers with wide confidence intervals (Agus et al., 2013a; IPCC, 2014). Peat profiles can be several meters deep, so their carbon storage can be an order of magnitude more than any forest. For example, the carbon stock in $1 \mathrm{~m}$ of peat (200-864 $\mathrm{t} \mathrm{C} \mathrm{ha}^{-1} \mathrm{~m}^{-1}$; Shofiyati et al. 2010; Agus et al. 2011) is one to three times that of aboveground biomass in an old-growth rainforest. Although the aboveground biomass of forests on peat is less than that on mineral soils, converting natural forest on peat leads to much higher carbon emissions, for two reasons: 1) if fire is used in land clearing, or escapes in the landscape owing to clearing elsewhere, several decimetres of peat can burn; 2) in drained peat, soil microbes can decompose the substrate and lead to a subsidence rate of initially several centimetres per year, with additional subsidence owing to compaction of the peat; subsidence influences water management and is used as indicator of carbon emissions, after correction for compaction (see below).

While mud is a disrespectful synonym of peat, mudslinging is not uncommon in the public debate on the topic, with considerable environmental and economic values at stake. Owing to the complexity of the issues across scales and stakeholders, 'muddling along' describes the response so far. Modelling approaches offer opportunities to clarify the assumptions, uncertainties and extrapolation domains based on scarce data and limited understanding; however, current models fall short of this ambition. A fundamental understanding of peat and peatland dynamics is certainly needed as the basis for appropriate policy responses, but the current debate on policy and economic incentives to reduce emissions are several steps beyond understanding of the basic processes. Added to this complexity are the many social, ecological, economic, policy-oriented, engineering, management and biophysical aspects of real-world systems, plus the need to effectively communicate interventions in the context of local ecological knowledge, traditional rule systems, local stakeholder preferences, and the language and mindsets of government officials. Together, these factors generate a situation of near intractable complexity.

From the perspective of reducing global emissions from all land uses, uncertainty over emission rates from peatlands hardly affects the conclusions about which land uses are desirable, but it does matter if reductions are to be quantified as a basis for economic incentives. This poses an interesting game theory challenge: proponents of converted-forest land uses may seek to portray low environmental impact by using the lower end of the range of measured emissions, whereas those who expect to benefit from rewards for emission reduction 
may use the higher end of the range as a baseline to maximize pay for subsequent reductions. High stakes in combination with complex causal pathways and contested methods have been the basis of a fierce debate, as noted above. We hope to contribute to an emerging clarity of how an interdisciplinary science of tropical peatlands can inform policy making at (sub-) national scales in dialogue with local stakeholders. The Reducing Emissions from Deforestation and Degradation through Alternative Land Uses in Rainforests of the Tropics (REDD-ALERT) project (Matthews et al. 2014) has engaged with the science as well as with policy responses on this issue, and some lessons have been learnt at the science-policy interface.

Despite substantial investments of time, capital and human resources there is as yet little agreement about definitions and measures of knowledge production and how this can be achieved to bridge multiple interests, powers and perspectives (Crona and Parker 2012). The United Nations Intergovernmental Panel on Climate Change (IPCC) has been a prime example of an institution at the global science-policy boundary (Miller 2001, Hulme and Mahony 2010), but the connection of knowledge to action is needed at all relevant scales to relate the science of climate change to emerging policy actions and negotiated behaviour changes in tropical forest margins (Clark et al. 2011). Three types of application (general interest, decision support and multi-stakeholder negotiation support) imply that the characteristics of usable knowledge shift from credibility, to credibility plus salience, with legitimacy coming to the foreground where real economic and political interests are at stake (Clark et al. 2011). We will reflect on the progress in usable peatland emission knowledge against this framework in the past five years towards action on reducing emissions from tropical peatlands. We will also characterize existing models and summarize the contributions of papers in this issue plus some related work recently published elsewhere, in the framework of this knowledge value-addition chain that may lead to real-world change if its weak points are strengthened. Indonesia harbours approximately half of tropical peat carbon stocks (Page et al. 2011), even though a recent reassessment by Ritung et al. (2011) came to lower estimates of the area, especially in Papua province, and the total numbers are uncertain. Peatlands in the western Amazon start to get international attention and may have so far been underestimated (Kelly et al., 2013), while studies in the Congo and Lake Victoria basin are in an early stage (Dargie et al., 2012; Yemefack, pers. comm.; Farmer, pers. comm). In line with the prominent role that the country has so far had in emissions due to peatland conversion to other land use, most of our discussion refers to Indonesia.

\section{Methods: a knowledge value chain}

Similar to the stepwise conversion of raw materials to tradable commodities, branded products, consumer-oriented services and highly valued experiences that are described in economic value chains with a focus on the value added in each step, we here describe a knowledge value (addition) chain, that potentially leads from raw data to positive impacts on lives and landscapes. From the literature and field experience, we inferred that at least four conditions need to be met before effective solutions to the peatlands emission issue can emerge (Fig. 1 and Table 1).

A. Basic understanding of the science, quantification methods and their possible bias, diagnosis of the land use practices leading to emissions and international recognition of the quantities involved and default values used in emission accounting.

B. Willingness to act to reduce emissions for any one or more of possible reasons (van Noordwijk et al. 2013, Gupta et al. 2013). 


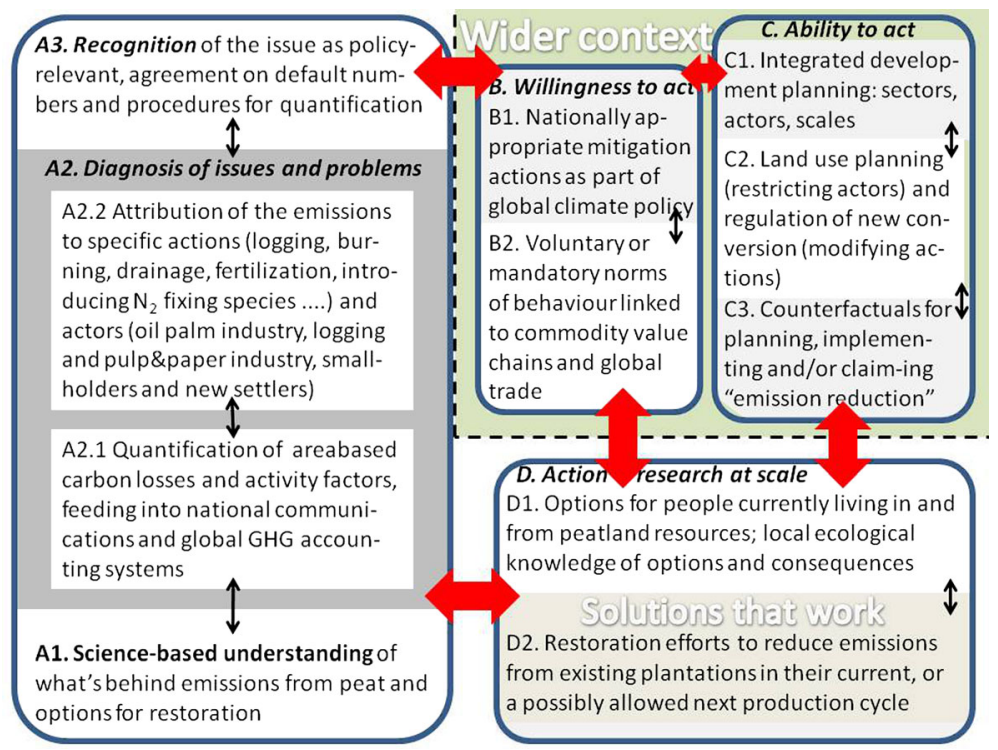

Fig. 1 Knowledge value-chain and its primary links with tropical peatland issues

C. Ability to act by relevant authorities and institutions, influencing actors and actions that ultimately reduce emissions.

D. Viable alternative options that meet legitimate stakeholders' expectations.

$\mathrm{A}$ and $\mathrm{D}$ are specific to peatlands, $\mathrm{B}$ and $\mathrm{C}$ are more generic aspects of land-based emission control. It is a value chain, in the sense that unless step A provides a credible account of the issue, it can be easily dismissed as irrelevant. Steps B and C add the salience dimension of potential policy-level decisions (B) and their implementation (C). Without step D, however, such change will not be seen as legitimate. The chain concept does not imply that all efforts have to go into the first step before the others become relevant. Rather, frequent reflection on what currently is the weakest part of the chain can increase the overall effectiveness of efforts.

The figure and table are based on our engagement with the learning curve of emission reduction in the context of the REDD-ALERT as international research project, plus other engagement as part of national and international research, academic explorations of the basic science and peer-reviewed literature, advice on emerging norms and rules in the private and government sectors, and participation in public discourses that continuously shape and reshape the issues.

\section{Knowledge chain transitions}

Along the knowledge value-chain that leads from fundamental understanding to action, there are several shifts in basic accounting units and associated challenges to temporal and spatial scaling. Accounting units shift from $\mathrm{C}$ stock in a unit volume of peat anywhere in the profile ( $\mathrm{mg} \mathrm{C} \mathrm{cm}{ }^{-3}$ ) to a gaseous flux per unit soil mass or volume $\left(\mu \mathrm{g} \mathrm{CO}_{2} \mathrm{~g}^{-1}\right.$ (dry weight) $\mathrm{hr}^{-1}$, or $\mu \mathrm{g} \mathrm{CO}_{2} \mathrm{~cm}^{-3} \mathrm{~h}^{-1}$ ) to area-based expressions ( $\mathrm{mg} \mathrm{CO}{ }_{2} \mathrm{~m}^{-2} \mathrm{~h}^{-1}$ or $\mathrm{Mg} \mathrm{CO}_{2} \mathrm{ha}^{-1}$ year ${ }^{-1}$ ) at measurement point, field, enterprise and landscape scales and, further, through product-based ones for footprints per unit of harvested product $\left(\mathrm{Mg} \mathrm{CO}_{2} \mathrm{Mg}^{-1}\right.$ product; Davis et al. 2013) to 


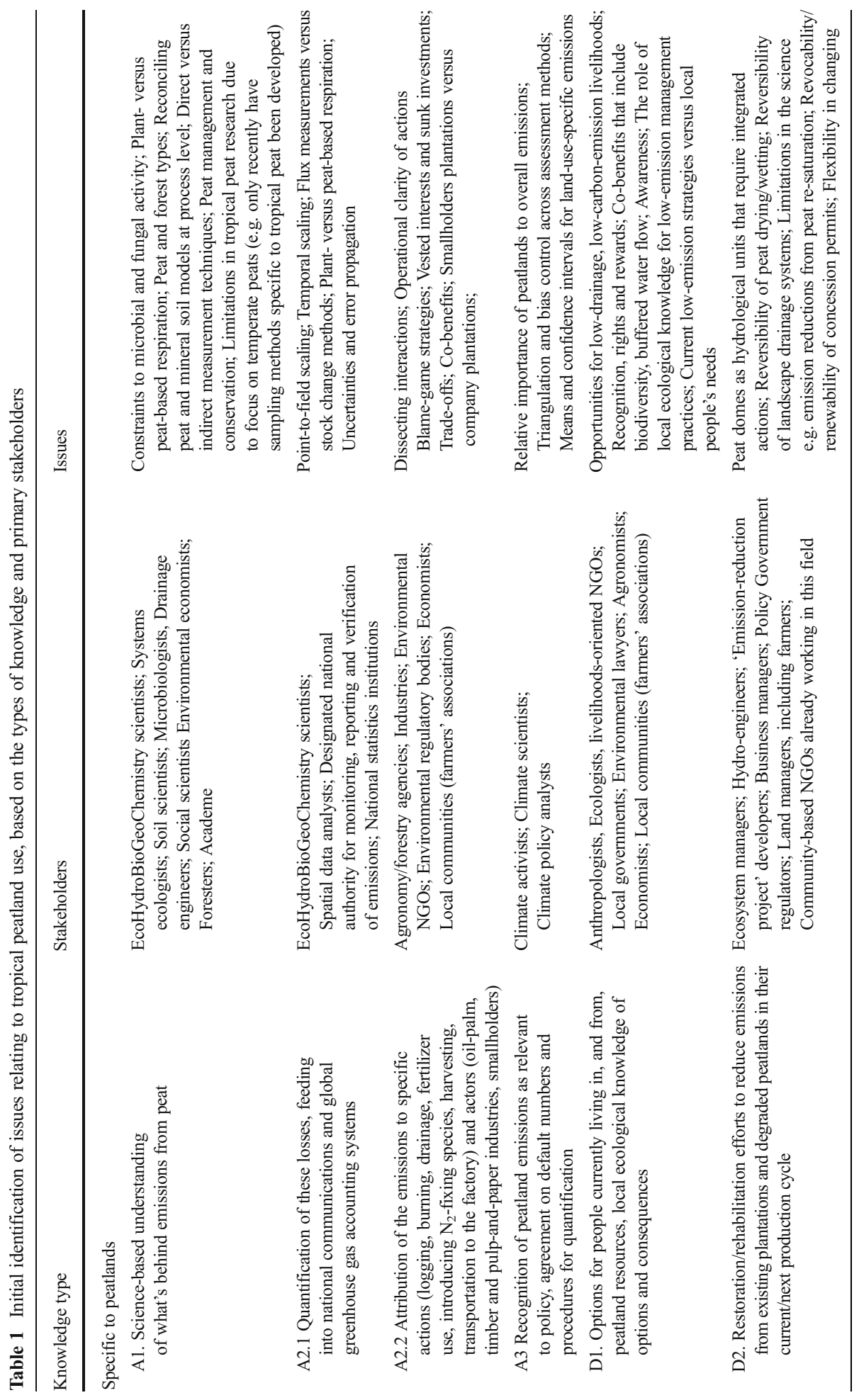




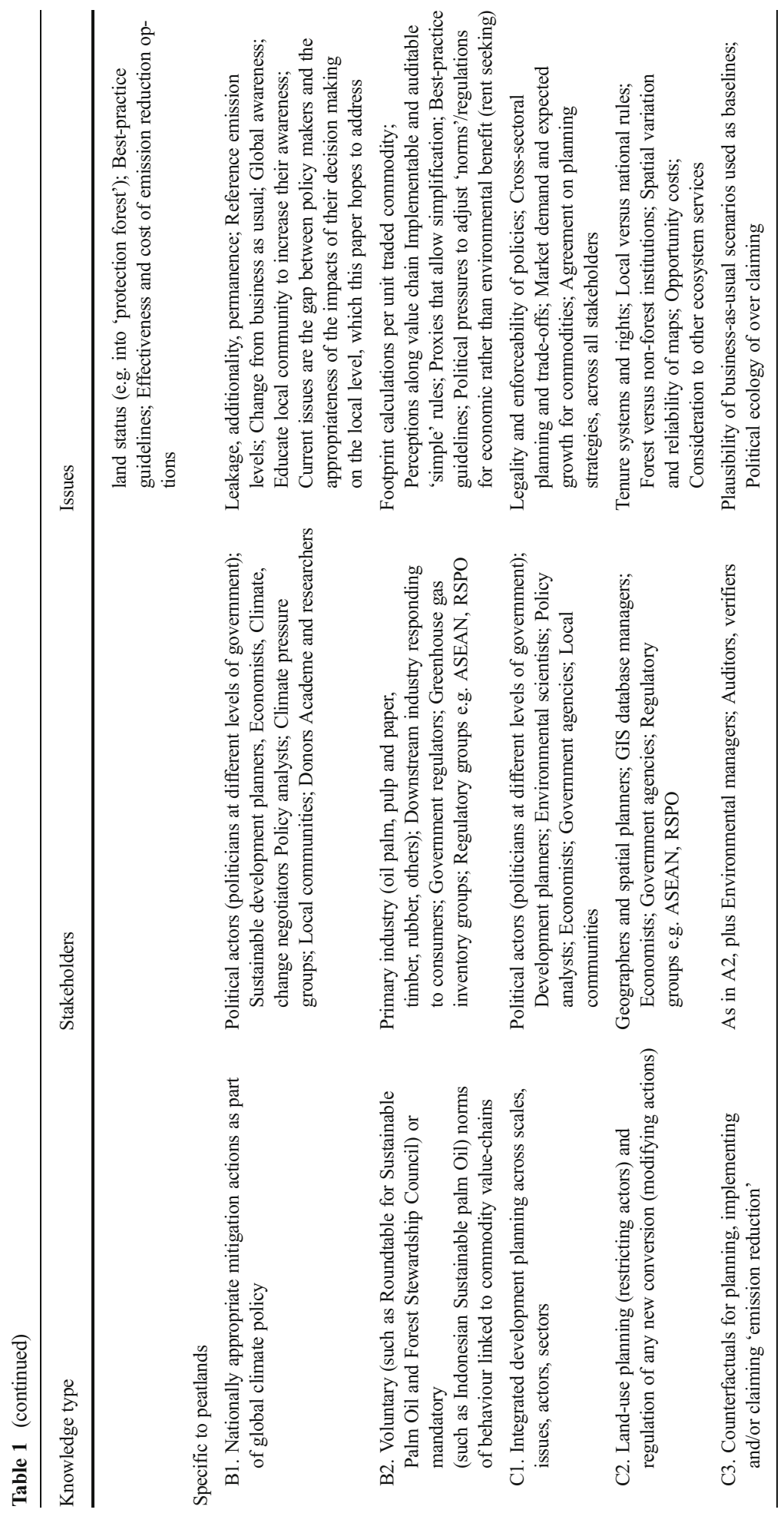


emission-based units for assessments of opportunity costs (USD $\mathrm{Mg}^{-1} \mathrm{CO}_{2}$ ) and emissionreduction strategies.

Conversion factors that link these units of analysis are crucial along this knowledge valuechain, such as yield that relates productivity to area and spatially explicit opportunity costs that link emissions to economics (van Noordwijk et al. 2013). The fundamental understanding of gaseous emission processes usually represents an hourly change dynamic and the basic unit of flux data collection is less than an hour; area-based emission estimates, however, are typically expressed per year (Groffman et al., 2006), while economic assessments require a life-cycle analysis, which may well mean a 25 year period for plantation crops.

In parallel, the basic data collection point needs to be interpreted in a wider spatial scale associated with management zones within plantation crops (Dariah et al. 2014) and field drainage patterns before expanding the scale to farm or enterprise management units, the aggregation of areas associated with an oil-palm mill or pulp-and-paper processing plant, and the nested governance systems that link villages to district, provincial and the national levels.

\section{Results: progress on issues along the knowledge value-chain}

\subsection{A1. Fundamental understanding}

Figure 2 provides a nested, Russian dolls, perspective on the steps that relate the primary interest of international stakeholders for total net emissions from a country through the location- and actor-specific concepts of land use and dominant practices-including the use of fire, drainage and fertilizers - to the microbial and plant-related processes that drive the flux of greenhouse gases across soil surfaces. A number of models cover parts of this (Farmer et al. 2011), but there is no comprehensive approach as yet.

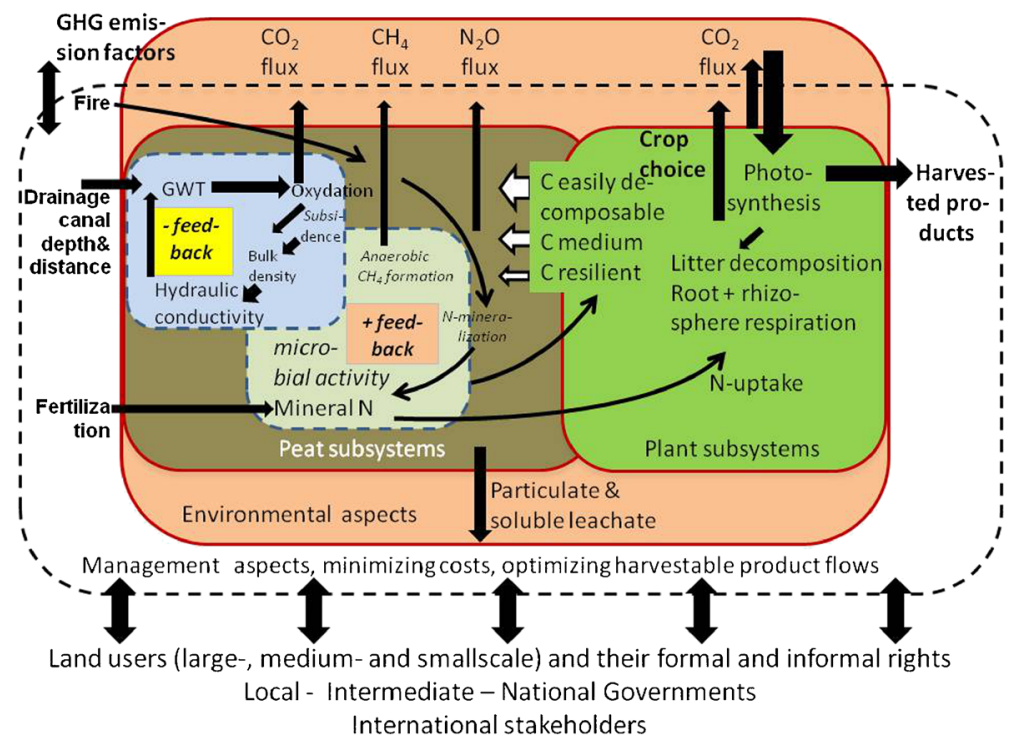

Fig. 2 Nested-scale relations between stakeholders' concerns and basic peat-level processes that determine emissions; GWT ground water table 
Peat starts to accumulate wherever the rate of organic deposition exceeds the rate of decomposition, which is due to a combination of environmental conditions, such as temperature, oxygen supply and $\mathrm{pH}$, and intrinsic properties of the organic matter, such as low nutrient content. In the tropics, decomposition rates are not limited by temperature or its seasonal variation. The primary trigger for organic matter accumulation in the form of peat is excess rainfall over drainage, as tends to occur in flat terrain on less permeable soils or in contact with a permanent groundwater table. Not all wetlands become peatlands, however, and the starting point of a self-reinforcing path to low nutrient content and low $\mathrm{pH}$ is not yet fully predictable. Forest vegetation that dilutes available nutrients in a large organic matter pool is often needed for tropical peat formation to start, but dry-season fires remove organic matter and increase $\mathrm{pH}$ and nutrient content. In the reverse process - where peat decomposition exceeds organic matter deposition — drainage plays a major role but the auxiliary roles of $\mathrm{pH}$ and nutrient supply are gradually being recognized (Handayani et al. 2010, Maswar 2011, Hergoualc'h and Verchot, 2013).

\subsection{A2.1 Quantification}

Correlation of emission estimates with groundwater table parameters across landscapes with different drainage intensity are normally interpreted as evidence of direct effects (Couwenberg and Hooijer 2013). There are some complications with this interpretation, however. Microbial respiration in batches of peat taken from various layers of the profile is related to water content via an optimum curve rather than a linear function (Husen et al. 2013). A peat profile consists of layers with different water content at any point in time while gas diffusion to the surface is influenced by the air-filled porosity of each layer. Short-term variations in the groundwater table or water content of the peat in the surface layers are, however, only weakly related to the concurrent surface flux of $\mathrm{CO}_{2}$ (Marwanto and Agus 2014). This might be expected as, for any groundwater table beyond a certain level, some peat layers may have the soil water content for maximum microbial activity. The aggregate surface flux is a weighted sum of respiration from all layers modified by transport constraints and time lags. Short-term variation in water content may influence the time lags and obscure a relationship between profile-level respiration and surface flux, but it may also be that profile-level respiration depends on which layers have the optimum water content for microbial activity. The seasonal variability in fluxes as affected by groundwater table variation may be more pronounced in undrained land uses as compared to drained ones (Comeau et al., 2013). Results of a comparison of the short-term drought impacts on peat samples from undisturbed and drained peat, however, suggested a substantial change in organic substrates and microbial activity due to drainage, increasing vulnerability to drought and release of $\mathrm{CO}_{2}, \mathrm{CH}_{4}$, and dissolved organic carbon compared to pristine peatlands (Kwon et al., 2013). Hirano et al. (2014) suggested that the instantaneous relationship between peat decomposition and groundwater table on a burnt peat profile is strongly non-linear, with the strongest effects for the first $40 \mathrm{~cm}$ of water table depth below the surface; they did, however, at an annual basis find a direct linkage between emissions and groundwater table on their site, in contrast to results reported by Marwanto and Agus (2014).

Added to this paradox, observations of a day-night rhythm in surface flux (Marwanto and Agus 2014), beyond what the modest variation in soil temperature can account for, point to a role for root-based respiration in the total surface flux. It may well be that in unravelling the role of drainage in the flux, the response of plant-root systems by mortality and re-expansion of fine roots over a time frame of weeks - supplying substrate for respiration in both phasesplays an important part in the overall response on an annual time scale that is not reflected in the daily pattern. 
As the distinctions between peat- and plant-based respiration are key to the policy-relevant interpretation of surface flux for annual carbon budgets as emissions or recycling, we analyzed the underlying science and concepts. While there is no reason to assume that peat- and plantbased respiration are directly interacting or respond in similar ways to external variation, the use of fixed fractions to split measured surface flux into peat- and plantbased respiration is an assumption that may fail beyond calibration ranges. The peat literature has settled on a rather peculiar terminology, where the ecologically relevant distinctions between the substrates that are decomposed (peat versus recent photosynthates) is confounded with terms that refer to respiration actors: heterotrophs versus autotrophs, without or with photosynthesis as the primary source of energy. A substantial share of the respiration of recent photosynthates is due to microbes in the rhizosphere of plants, or consuming products of root turnover, hence this is heterotrophic. Yet all plant-based respiration is often termed autotrophic. Dariah et al. (2013) was the first paper to clarify that the relevant distinction is between peat- and rootbased, rather than between auto- and heterotrophic respiration. There is a further possibility that the presence of plant roots increases the heterotrophic decomposition of peat: rootinduced, peat-based respiration in which underlying mechanisms can be the change of aeration with aerenchyma in roots allowing gas exchange and/or through priming of microbial activity. The latter is known from mineral soils (Bader and Cheng 2007) where nutrient and carbohydrate leakage into rhizosphere soil either stimulates (up to doubling of background rates) or inhibits microbial breakdown of soil carbon. Such effects have not been demonstrated for peat soils, but they cannot be excluded and they would complicate the interpretation of any spatial association of roots and respiration as indicative of plant- rather than peat-based respiration.

Murdiyarso et al. (2010) and Hergoualc'h and Verchot $(2011,2013)$ used measurements of peat respiration, litterfall rate and fine root turnover as the basis for their correction factors to convert flux data to emission estimates. In a direct comparison of rooted and non-rooted ingrowth cores, up to four-fold increases of respiration due to roots were noted (Agus et al. 2010). Dariah et al. $(2013,2014)$ used the spatial pattern of surface flux measurements with increasing distance from oil palms as a basis for estimating plant-based respiration. The surface flux was highest close to oil palms and decreased towards the zone in between palm trees. They estimated accordingly that peat-based respiration accounted for $86 \%$ of $44.7 \pm 11.2$ and $71 \%$ of $47.8 \pm 21.3 \mathrm{Mg} \mathrm{CO}_{2} \mathrm{ha}^{-1}$ year $^{-1}$ of weighted surface flux, respectively, for 6 and 15 year-old plantations. As the measurements at greatest distance from the palm were not completely free of vegetation, nor of palm roots, their estimates of peat-based respiration may be on the high side. A method used by Husnain et al. (2014) to keep areas of peat free from vegetation to directly measure peat-based respiration may provide an overestimate because decomposition of root necromass left after removal of aboveground biomass probably contributed to the surface flux. Farmer (2014) reported peat emissions from measurements on areas without aboveground vegetation in the range $20-40 \mathrm{Mg} \mathrm{CO}_{2} \mathrm{ha}^{-1}$ year ${ }^{-1}$ for 4-7 year old oil palm. Current quantification of all interacting processes in these measurement conditions is insufficient to fully rely on measurements of surface flux alone if peat-based respiration is the primary interest.

A current point of discussion (Maswar, 2011; Hergoualc'h and Verchot, 2013) is the effect of fertilization and nutrient availability on peat-based emissions in plantation crops as well the possible increase in emissions where well-nodulated, Nitrogen $\left(\mathrm{N}_{2}\right)$ fixing trees enrich the rooted volume of peat with nitrogen. However, the time course of increased surface flux after a fertilization event can be due to both microbial and root responses. Further empirical data is needed, along with process-based models that relate a rooted-soil volume scale to a rooted peat soil profile.

The rate of subsidence of the soil surface in drained peat is an indication of peat loss at annual and multi-annual scales, provided that compaction of the profile is accounted for 
(Hooijer et al. 2012). Measurement of subsidence can document the change over time of subsidence rates in a single location (Hooijer et al. 2010). The subsidence method records net changes in peat $\mathrm{C}$ stocks, regardless of their nature: peat, belowground biomass or necromass. Emission estimates derived from subsidence have considerable uncertainty and wide confidence intervals, however, because there is short-term swell and shrink of the peat surface in response to water content (similar to swell and shrink of tree diameters as noise in allometric biomass relations), as well as short-range variation in peat density and considerable bias and random error in peat bulk density measurements (Maswar et al. 2013). Time-dependence of subsidence rates at a given drainage depth are indications that unidentified parameters that are themselves time dependent, influence peat decomposition, as we cannot assume that microbes know the time since drainage started. Compaction and structural changes in the peat due to decomposition of the root system of previous vegetation, a $\mathrm{C}$ stock of higher decomposability than peat, may be involved. Assuming a constant oxidation/compaction ratio, as is commonly done in converting subsidence to emission rates, is probably not appropriate. Peat swamp forests differ in tree density, biomass and carbon content in relation to distance to rivers or the edge of the peat dome, with a change in the fraction of trees with pneumatophores as indicator of different aeration conditions (Campbell, 2013). The way drainage canals are superimposed on natural patterns of vegetation and peat variation is a challenge for all survey-based data interpretation that tends to have implicit assumptions of homogeneity.

A third method was applied to tropical peats by Maswar (2011) and involved the use of ash as a conservative tracer. If we can assume that the minerals measured as residue on ignition of peat are not subject to significant increase or decrease, then the increase in ash concentration over time can be used to calculate the loss of organic substrate (Maswar et al. 2013). This third method primarily depends on an assumption of predictability and homogeneity of the ash content of peat prior to conversion. Bands of ash in peat profiles, due to past burns or flooding, indicate that this assumption of homogeneity is not always applicable but it is reassuring that the three methods give similar results when tested at the same location (Handayani et al. 2010, Maswar 2011). If additional assumptions are made on the import and export of ash as part of particulate matter during fires - and of the ash content of biomass - then ash measurements can also be used to estimate the losses of $\mathrm{CO}_{2}$ to the atmosphere owing to fire. This method has been further developed for application to oil palm (Eleais guineensis) plantations (Farmer, 2014).

Despite high hydraulic conductivity, undrained peat domes may release most of their excess rainfall through runoff and overland flow, rather than groundwater pathways (Kelly et al. 2013); this situation changes upon drainage, with potential consequences for an increased export of soluble organic compounds (Gandois et al. 2013). In the overall carbon budget, however, this represents only a small term (Hergoualc'h and Verchot 2013).

\subsection{A2.2 Attribution of emissions}

Beyond contributing to emission estimates that are valid at the spatially aggregated scale of a district, province or country, the recognition of emission factors for land-use categories that can be multiplied by the associated area (Agus et al. 2013a,b, Gunarso et al. 2013) can help in identifying the opportunity costs of emission reduction because economic analysis is best done at the scale of a land-use system. A step in that direction is the attribution of emissions to specific actions - such as logging, burning, drainage, fertilization and introduction of $\mathrm{N}_{2}$-fixing species - out of which the emission factors of a land-use system can be constructed specific to peatland land use actors, such as smallholders and the oil-palm, timber and pulp-and-paper industries.

While process-level studies are challenging, early results that relate annual emissions to the depth of the groundwater table (Hooijer et al. 2006, 2010) have been used as the basis for 
extrapolations to land uses that differ in drainage intensity. Drainage depth is the primary driver in the The Tropical Peatland Plantation-Carbon Assessment Tool (TROP-CATT) calculator scheme (Farmer et al. 2014), derived from the Hooijer et al. (2012) model. It is, however, not free from ambiguity because the depth of the groundwater table varies in time and space in response to rainfall patterns, the hydraulic conductivity of the peat, distance between drains and the way the water level in drainage canals fluctuates in response to outflows from the drained area as a whole. There seems to be a consistent difference between smallholders' drainage patterns (closely spaced but shallow) and the patterns used in large plantations (fewer but deeper canals), with important consequences for the spatially averaged depth of the groundwater table, even if all systems are compared at a drain intensity that meets the requirements for the wettest position in the field. Empirical studies, however, tend to find only weak relations between surface flux and distance to the drainage canal (Marwanto and Agus 2014; Maswar 2011), possibly because the responses of root systems to the seasonal pattern of water content interact with the response of the peat.

While fine-tuning of the attribution is a necessary step to judge the relevance of adjustments within a land-use system to reduce emissions, policy processes require clearly identifiable categories and default values for accounting. In response, efforts so far have been focussed on using the land use of a measurement point as the primary identifier even though many studies have found that landscape-level drainage effects may dominate over land use: forests or nonvegetated areas in landscapes affected by drainage can have a surface flux that exceeds that of a plantation crop measured in the same landscape (Agus et al. 2009, Husnain et al. 2014, Maswar 2011).

\subsection{A3. New IPCC default values differentiate between between land uses on peat}

In October 2013, the IPCC accepted, and in March 2014 published, a revision of the measurement methods for wetlands, which included new default values for tropical peat soils brought into cultivation. While details of the discussion in the working group are not public, the discussions met the expectation of close scrutiny of all data sets and the contested interpretation of outliers. In the end, the IPCC accepted a system where the means of accepted data sets serve as default values (IPCC 2014). An important, but contested, step in the debate was to separate the data of Acacia plantation forestry and oil palm. The former was mostly based on one study site and was higher than the average of other data accepted for oil palm. It may also be, however, that a different type of peat with higher vulnerability was converted to the plantations investigated, with uncertainty on whether this represents current forestry practice. Another reason for the difference in measured emissions can be that $\mathrm{N}_{2}$-fixing Acacia might enrich the $\mathrm{N}$ content of peat and hence speed up microbial breakdown and $\mathrm{CO}_{2}$ release whereas under other land uses microbes remain $\mathrm{N}$-limited. It could also be due to the fact that Acacia is densely planted and harvested every 6 years on average, which disturbs the soil surface more frequently and more intensely than in widely spaced oil palm that is renewed on 25 year cycles. This may be an example of where the policy making is ahead of the science - further field work is needed to clarify the mechanisms involved to modify the relevant models.

\subsection{B. Willingness to act}

In the eyes of politicians, the primary policy issue related to peatland conversion is still haze derived from fire, the diplomatic embarrassment this causes if neighboring countries complain, direct health risks and disturbance to aviation (Mahmud 2013). Emission reduction is only 
a secondary argument for policy interventions. If no-burn policies were to be effectively implemented, which currently they are not (Ekadinata et al. 2013), the peatlands agenda might lose its political traction, unless performance-based financial incentives to reduce emissions will materialize at the scale required, which currently they are not (yet). Earlier analyses of the environmental damage resulting from peatland conversion (Diemont et al. 2001) were largely ignored in the policy debates of the time. However, when the estimates of emissions from peat fires were converted from an incomprehensible number of megatons (Murdiyarso and Adiningsih, 2007) to the easier to understand ranking of countries, Indonesia was identified as the third-largest emitter of greenhouse gases in the world (IFCA, 2008; Hasegawa and Matsuoka, 2013). This occurred just before the 2007 Conference of Parties to the Framework Convention on Climate Change in Bali, Indonesia. The Indonesian public response was one of denial. Very few Indonesian scientists had been involved in the research that generated the high emission estimates and this provided a fertile ground for conspiracy theories, especially when the publicity on emissions started to threaten exports of palm oil from the country. Van Noordwijk et al. (2014) described the shifts in motivation in emission-reduction discourse, from expectations of REDD + rents through branding and safeguarding of exports to the selfarticulation of co-responsibility for global climate dynamics. Specifically for Indonesia, the early interest in implementation of REDD + included peat areas that might have been beyond the technical scope of REDD + within the prevailing definition of 'forest', effectively paving the way for an approach targeting the reduction of emissions from all land uses (Bernard et al. 2013). While prospects for inclusion of other belowground carbon pools as part of carbon markets are still limited by the costs of reliable measurement of changes (van Noordwijk 2014), the magnitude of avoidable emissions from peat justifies the measurement cost.

Specific to the acceptance of peat issues as part of Indonesia's willingness to act was the active role of Indonesian scientists at the Ministry of Agriculture and key universities, who conducted further research on emissions. Indonesian scientists are now contributing to the increasing body of empirical evidence and to the identification of factors other than drainage depth as predictors of site-specific emissions. Scientific debate at universities and government research centres are intensifying and the available evidence is scrutinized. Accepting considerable spread around midpoint values, there is now widespread acknowledgement that reducing peat-based emissions, whether inside or outside forests, is an important part of national strategies to reduce emissions from what was considered to be a 'business as usual' scenario. Based on the research and grasp of its own scientists, the Government of Indonesia has been able to challenge the accounting scheme (model) and key parameters used by the environmental protection agency (EPA) of the USA for estimating the carbon footprint of palm oil produced in the country and achieved some corrections on the scheme proposed. Similarly, data collection on oil palm plantations together with the plantation companies, using a transparent accounting model (van Noordwijk et al. 2013), helped to increase understanding and acceptability of the results, while Indonesian scientists led efforts of the Roundtable for Sustainable Palm Oil (RSPO) to review the accounting scheme and relevant literature (Agus et al. 2013a,b).

\subsection{Ability to act}

Ability and willingness to act on peatland emissions is closely associated with willingness and ability to deal with emissions from any land use. Peatlands are a rather hostile environment for humans. Peat areas were largely bypassed by economic development when new areas with mineral soils could still be exploited. Increasing conflict over land rights in forests on mineral soils, however, made the sparsely populated peat swamps attractive to the agricultural and 
forestry industries based on oil palm and pulp and paper. While permits for such conversions from the central and local governments could be easily obtained with cash payments and promises of local employment and economic development, reversal to a lower-emissions trajectory, even if this is now seen as desirable, is not easy to achieve. Permits have already been issued for large areas that have not yet been converted (Carlson et al. 2013). These cannot be easily withdrawn. In other cases, conflicts have arisen between different layers of government about the authority to issue and withdraw permits (Tata et al. 2014, Galudra et al. 2011). Unclear and contested tenure contributes to land claims through use of fire (Medrilzam et al. 2013). Conversion of peat swamps usually requires availability of labour beyond what exists locally, so migrant labour tends to be an important prerequisite for conversion. Migrants often enter into complex transactions to acquire land-use rights under local customary rules rather than through legally recognized channels (Galudra et al. 2014). For local governments, it is important to be assured of integrated development scenarios that meet local expectations. External investment, government revenue generation and employment in emission reduction scenarios must be at least equivalent to business as usual. In this context, the incentives switch from a choice of emission factors at the low end of the measured spectrum to make current practices look less negative to one that prefers the high end as a baseline because this allows large claims of reductions. Among the various contested new rights in the carbon market era, the rights to set a baseline and to carry out measurements are now recognized as having direct economic impacts. The model used for economic incentives is focused on the difference between actual land use and what can be claimed to have been a business as usual scenario without additional policy interventions. Thus, the models shift from an understanding of emissions given land use practices, to an understanding of land use change.

The willingness and ability to act on peatland issues is part of the wider dynamic of the relevance of a shift to a cleaner, low-emissions, development pathway across all sectors of the economy, and the multiple elements of motivation to do so (Jupesta et al. 2011; Murdiyarso et al. 2013; van Noordwijk et al. 2014). The ability to act on the basis of evidence requires a competent local government that is on top of the way emission reductions are calculated and valued. While the issues of prior and informed consent of local communities have rightly received much attention in the REDD + debate, the capacity of local governments to play the required role is still a critical step, with noticeable positive exceptions. These exceptions tend to occur in combination with action research identifying solutions that are fully operational (D).

\subsection{Viable alternative uses of peatlands}

The simplest way to avoid emissions is to leave peatlands alone, but in many areas the process of drainage has been started and is not easily reverted. In the specific case of the failed mega rice development project in Central Kalimantan, Indonesia, active ecological restoration has been attempted by rewetting the area through canal blocking, as a way to reduce fire risk and reduce emissions (Jauhiainen et al. 2008). Ritzema et al. (2014) reviewed the experience so far and found that the resulting higher water tables did not completely compensate for the negative effects of increased subsidence near the canals, which have become depressions in the peatland surface leading to interception of overland- and interflow and increased risk of overtopping of dams during extreme rainfall events. Yamamoto et al. (2013) commented on the absence of incentives for households in the central Kalimantan peatland restoration areas to engage in fire control. Graham (2013) explored how a combination of ecological-technical and socialpolitical perspectives is needed in restoration ecology for degraded peat forests in Central Kalimantan. While her ecological investigation revealed that seed rain, animal-dispersal, flooding, increased light levels and lowered soil nutrient and mycorrhiza levels had become 
barriers to forest regeneration, focus groups and interviews revealed other factors influencing forest regeneration (Graham et al. 2013); the community's lack of livelihood options, their dependency on the forest, the lack of funding for restoration and their dislike of 'outsiders'. Integrating these perspectives may lead to new approaches in peatland restoration.

Beyond these restoration landscapes, the primary issues are to slow down or redirect current land use change. Indonesia's moratorium on the further conversion of peatland (Murdiyarso et al., 2011) provides some respite for reconsideration of development priorities for local and national governments. Where the livelihoods of local people with sufficient history are involved (the transition from 'migrant' to local status is, however, fuzzy), the investment in viable livelihood alternatives is the key to acceptance of other trajectories, rather than payments for reduction of emissions per se (Namirembe et al. 2014). Case studies (Tata et al. 2014, Mulia et al. 2014) have explored tools and models for analysing the opportunity costs involved in reducing emissions and projecting them into analyses of scenarios for alternative livelihoods. Beyond the possible revival of value chains for trees native to peat swamps, including Dyera polyphylla ('peat jelutung'), the option of ecotourism is often mentioned. This can be an opportunity for selected places of good general accessibility but cannot be expanded in scale to meet the extent of the challenge of generating adequate alternative livelihoods.

There is growing recognition that smallholder agroforestry systems in the edges of peat ecosystems have developed drainage systems that are sufficiently effective to allow rubber (Hevea brasiliensis), excelsa coffee (Coffea liberica), pinang palms (Areca catechu) and local fruits to thrive without causing high emissions (Sofiyuddin et al. 2012). Specific research to further improve such systems without increasing emissions is needed. Valuable peatland trees, such as Alseodaphne spp. ('gemor') that is overexploited in the wild as its bark is a major insect repellent, could be included in such systems, if more effective propagation methods can be found (Janudianto et al., 2011). Integrated approaches to local livelihood development are still needed. The planning tools and models exist and provide a basis for local negotiations (Ekadinata and Agung, 2011), but there is a dearth of economically and socially viable solutions to make the alternatives attractive.

In the United Nations Framework Convention on Climate Change (UNFCCC) meeting in Durban in 2011, a decision was made to include incentives for emission reduction from degrading peatlands under the Kyoto Protocol for Annex-I countries and under the emerging REDD ${ }^{+}$for developing countries. This implied that the operational forest definition would no longer be the defining element of REDD+. It opens the door to larger scale support for what have so far been pilot projects in microcredit finance mechanisms, where effective emission reduction is used to pay back loans (van Eijk and Kumar, 2009). Structural international support for integrated land use policies are beginning to emerge in the international community, but will have to be long-term to shape future peatland management in ways that support local livelihoods.

\section{Discussion}

Our quick tour of the issues associated with reducing emissions from tropical peatlands suggests that there is some progress in all four requirements for mitigation action, basic understanding (a), willingness (b) and ability (c) to act and effective alternative land uses (d), but that progress has been uneven. While the lack of legitimacy of peatland science (a) from a national perspective contributed to the denial and conspiracy theory stage of the public response (b), it has been effectively overcome in recent years.

The knowledge to action framework (Cash et al. 2003; Clark et al. 2011) on salience, credibility and legitimacy of scientific knowledge, appears only to focus on steps A and B of 
the knowledge-value chain as described here. We found some evidence that lack of legitimacy, from a national perspective, of the early peat science limited its effectiveness, and that direct involvement of national scientists enhanced the willingness to act. Change in the ability to act step $\mathrm{C}$ involves many external conditions and policies beyond knowledge alone, and in a knowledge-to-action framing existing limited ability to modify existing contract, as is discussed in the 'land grab' literature (Zoomers, 2010), may have to be taken into account.

Given the progress achieved on $\mathrm{a}, \mathrm{b}$ and $\mathrm{c}$, it now seems that stage D has become the limiting step of the knowledge-to-action value-chain. If good science, accurate numbers, a willingness and ability to act on emission estimates are not accompanied by viable alternatives for local livelihoods then the ultimate goal of reducing emissions cannot be achieved. Further efforts in this field may need a strong emphasis on action research that targets locally appropriate adaptation and mitigation actions to ensure that Nationally Appropriate Mitigation Action plans can become a reality. The goal of glocal (Gupta 2012) actions to reduce peat emissions is primarily constrained by the lack of local options.

In trying to understand the functioning of hierarchical socio-ecological systems, Gunderson and Holling (2001) conceived the rule of hand in that there were usually only a few variables (typically four to five) operating at a particular level that influenced processes occurring at a higher level. The challenge is to identify which variables these are, but the use of models is one way of helping us to do that. Models involve simplification of a system to its essential dynamics and control variables, omitting (at least in the first instance) all those processes that have little or no influence on overall system behaviour. They also allow testing of hypotheses about what is and what isn't important in these dynamics, something that is not practically possible (or ethically permissible in many cases) by manipulating real-world systems. Along the knowledge value chain the key variables shift from water, carbon, vegetation, fire and nutrients to another handful: livelihoods, sovereignty, commitment, reciprocity and economics.

The knowledge to action value chain involves multiple transformations. Just as a person travelling across multiple countries needs to be ready to speak different languages, convert currencies, deal with changing perspectives on legitimacy and have the passport and visa to appease authorities, but yet maintains a core identity, the ideas and knowledge that travel from academia to the multiple countries that may apply them need to be ready to be transformed. IPCC has been described as a boundary organization interfacing science and policy. Where mitigation of and adaptation to climate change require synergy between multiple layers where action is needed, the knowledge value chain depends on multiple steps of boundary work, without losing its core content and identity.

Acknowledgments The authors are grateful for financial support from the European Union under the Reducing Emissions from Deforestation and Degradation from Alternative Land Uses in Rainforests of the Tropics (REDD-ALERT) project (Grant Agreement no. 226310). This synthesis was supported by the CGIAR Research Program on Forests, Trees and Agroforestry. The authors have no other relevant affiliations of financial involvement with any organisation or entity with a financial interest in or financial conflict with the subject matter or materials discussed in the manuscript apart from those disclosed. Constructive comments from two anonymous reviewers helped to improve the manuscript.

Open Access This article is distributed under the terms of the Creative Commons Attribution License which permits any use, distribution, and reproduction in any medium, provided the original author(s) and the source are credited.

\section{References}

Agus F, Runtunuwu E, June T, Susanti E, Komara H, Syahbuddin H, Las I, van Noordwijk M (2009) Carbon dioxide emission in land use transitions to plantation. Jurnal Litbang Pertanian 28(4):119-126 
Agus F, Handayani E, van Noordwijk M, Idris K, Sabiham S (2010) Root respiration interferes with peat $\mathrm{CO}_{2}$ emission measurement. 19th World Congress of Soil Science, Soil Solutions for a Changing World. 1-6 August 2010, Brisbane

Agus F, Hairiah K, Mulyani A (2011) Measuring carbon stock in peat soil: practical guidelines. World Agroforestry Centre-ICRAF Southeast Asia and Indonesian Centre for Agricultural Land Resources Research and Development, Bogor

Agus F, Gunarso P, Sahardjo BH, Harris N, van Noordwijk M, Killeen TJ (2013a) Historical CO2 Emissions from Land Use and Land Use Change from the Oil Palm Industry in Indonesia, Malaysia and Papua New Guinea. Roundtable on Sustainable Palm Oil, Kuala Lumpur

Agus F, Henson IE, Sahardjo BH, Harris N, van Noordwijk M, Killeen TJ (2013b) Review of emission factors for assessment of $\mathrm{CO}_{2}$ emissions from land use change to oil palm in Southeast Asia. Roundtable on Sustainable Palm Oil, Kuala Lumpur

Bader NE, Cheng W (2007) Rhizosphere priming effect of Populus fremontii obscures the temperature sensitivity of soil organic carbon respiration. Soil Biol Biochem 39(2):600-606

Bernard F, Minang PA, van Noordwijk M, Freeman OE, Duguma LA (2013) Towards a landscape approach for reducing emissions: substantive report of Reducing Emissions from All Land Uses (REALU) project. World Agroforestry Centre - ICRAF, Nairobi, p 119

Campbell L A (2013) Disturbance effects on carbon content and tree species traits in tropical peat swamp forest in Central Kalimantan, Indonesian Borneo. Dalhousie University, Halifax (Canada) http:/www.outrop.com/uploads/ 7/2/4/9/7249041/lad campbell 2013 - bornean tropical peat swamp forests.pdf, assessed 28-2-2014

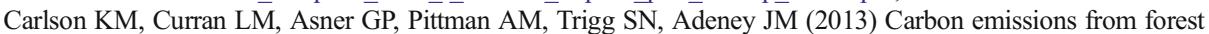
conversion by Kalimantan oil palm plantations. Nature Clim Change 3(3):283-287

Cash DW, Clark WC, Alcock F, Dickson NM, Eckley N, Guston DH, Jager J, Mitchell RB (2003) Knowledge systems for sustainable development. Proc Natl Acad Sci U S A. doi:10.1073/pnas.1231332100

Clark WC, Tomich TP, van Noordwijk M, Guston D, Catacutan D, Dickson NM, McNie E (2011) Boundary work for sustainable development: natural resource management at the Consultative Group on International Agricultural Research (CGIAR). Proc Natl Acad Sci U S A. doi:10.1073/pnas.0900231108

Comeau L-P, Hergoualc'h K, Smith JU, Verchot L (2013) Conversion of intact peat swamp forest to oil palm plantation: effects on soil $\mathrm{CO}_{2}$ fluxes in Jambi, Sumatra. Working Paper 110. CIFOR, Bogor

Couwenberg J, Hooijer A (2013) Towards robust subsidence-based soil carbon emission factors for peat soils in south-east Asia, with special reference to oil palm plantations. Mires \& Peat 12:1-13

Crona BI, Parker JN (2012) Learning in support of governance: theories, methods, and a framework to assess how bridging organizations contribute to adaptive resource governance. Ecol Soc 17(1)

Dariah A, Agus F, Susanti E (2013) Relationship between distance sampling and carbon dioxide emission under oil palm plantation. Jurnal Tanah Tropika (Journal of Tropical Soils) 18(2)

Dariah A, Marwanto S, Agus F (2014) Root- and peat-based $\mathrm{CO}_{2}$ emissions from oil palm plantations. Mitig Adapt Strateg Glob Chang. doi:10.1007/s11027-013-9515-6, this issue

Dargie G, Lewis S, Lawson I, Baird A, Page S, Mitchard E (2012) Quantifying and understanding tropical peatland spatial distribution and carbon storage in Central Africa. Proceedings of the 14th International Peat Congress, Stockholm. http://www.peatsociety.org/document/quantifying-and-understranding-tropicalpeatland-spatial-distribution-and-carbon-storage Accessed 28 May 2014

Davis SC, Boddey RM, Alves BJR, Cowie A, Davies C, George B, Ogle SM, Smith P, van Noordwijk M, van Wijk M (2013) Management swing potential for bioenergy crops. Glob Chang Biol Bioenergy. doi:10.1111/ gcbb. 12042

Diemont WH, Joosten H, Mantel S, Murdiyarso D, van Noordwijk M, Rieley JO, Veldsink JW, Verhagen A, Wakker E, Wind J, Setiadi B, Limin SH (2001) Poverty alleviation and wise use of peatlands in Indonesia. Int Peat J 11:79-88

Ekadinata A, Agung P (2011) Planning for low-emissions development in Tanjung Jabung barat district, Jambi province, Indonesia. World Agroforestry Centre, Bogor

Ekadinata S, van Noordwijk M, Budidarsono S, Dewi S (2013) Hot spots in Riau, haze in Singapore: the June 2013 event analyzed. ASB Policy Brief No. 33. ASB Partnership for the Tropical Forest Margins, Nairobi, p 6

Farmer J. (2014) Measuring and modelling soil carbon and carbon dioxide emissions from Indonesian peatlands under land use change. PhD Thesis. University of Aberdeen

Farmer J, Matthews R, Smith JU, Smith P, Singh BK (2011) Assessing existing peatland models for their applicability for modelling greenhouse gas emissions from tropical peat soils. Curr Opin Environ Sust 3(5): 339-349. doi:10.1016/j.cosust.2011.08.010

Farmer J, Matthews R, Smith P, Smith JU (2014) TROPP-CAT: A tool for estimating $\mathrm{CO}_{2}$ emissions from tropical peat soils under plantations. Mitig Adapt Strateg Glob Chang (MITI-D-13-00071). this issue

Galudra G, van Noordwijk M, Suyanto S (2011) Hot spots of confusion: contested policies and competing carbon claims in the peatlands of central Kalimantan (Indonesia). Int Forest Rev 13:431-441 
Galudra G, van Noordwijk M, Agung P, Suyanto S, Pradhan U (2014) Migrants, land markets and carbon emissions in Jambi, Indonesia: land tenure change and the prospect of emission reduction. Mitig Adapt Strateg Glob Chang. http://link.springer.com/article/10.1007/s11027-013-9512-9. this issue

Gandois L, Cobb AR, Hei IC, Lim LBL, Salim KA, Harvey CF (2013) Impact of deforestation on solid and dissolved organic matter characteristics of tropical peat forests: implications for carbon release. Biogeochemistry 114(1-3):183-199

Graham LLB (2013) Restoration from within: an interdisciplinary methodology for tropical peat swamp forest restoration in Indonesia. Doctoral dissertation, University of Leicester (UK).

Graham LLB, Turjaman M, Page SE (2013) Shorea balangeran and Dyera polyphylla (syn. Dyera lowii) as tropical peat swamp forest restoration transplant species: effects of mycorrhizae and level of disturbance. Wetl Ecol Manag 21(5):307-321

Groffman PM, Venterea RT, Verchot LV, Potter CS et al (2006) Landscape and regional scale studies of nitrogen gas fluxes. In: Scaling and Uncertainty Analysis in Ecology: Methods and Applications. Springer, Dordrecht, pp 191-203

Gunarso P, Hartoyo ME, Agus F, Killeen TJ (2013) Oil palm and land use change in Indonesia, Malaysia and Papua New Guinea. Roundtable on Sustainable Palm Oil, Kuala Lumpur

Gunderson L, Holling CS (2001) Panarchy: Understanding Transformations In Human And Natural Systems. Island Press, Washington

Gupta J (2012) Glocal forest and REDD + governance: win-win or lose-lose? Curr Opin Environ Sust 4:1-8

Gupta J, Mathews R, Minang P, van Noordwijk M, Kuik O, van der Gijp N et al (2013) Climate change and forests: from the Noordwijk Declaration to REDD. In: Gupta J, van der Grijp N, Kuik O (eds) Climate Change, Forests and REDD. Lessons for Institutional Design, Routledge, pp 1-24

Handayani EP, van Noordwijk M, Idris K, Sabiham S, Djuniwati S (2010) The effects of various water table depths on $\mathrm{CO}_{2}$ emission in an oil palm plantation in West Aceh on peat. J Trop Soils 15(3):255-260

Hasegawa T, Matsuoka Y (2013) Climate change mitigation strategies in agriculture and land use in Indonesia. Mitig Adapt Strateg Glob Chang. doi:10.1007/s11027-013-9498-3

Hergoualc'h K, Verchot LV (2011) Stocks and fluxes of carbon associated with land-use change in Southeast Asian tropical peatlands: a review. Glob Biochem Cy 25. doi: 10.1029/2009GB003718

Hergoualc'h K, Verchot LV (2013) Greenhouse gas emission factors for land use and land-use change in Southeast Asian peatlands. Mitig Adapt Strateg Glob Chang. doi:10.1007/s11027-013-9511-x, this issue

Hirano T, Kusin K, Limin S (2014) Osaki M (2014) Carbon dioxide emissions through oxidative peat decomposition on a burnt tropical peatland. Glob Chang Biol 20:555-565

Hooijer A, Silvius M, Wösten $\mathrm{H}$, Page S (2006) PEAT- $\mathrm{CO}_{2}$ : assessment of $\mathrm{CO}_{2}$ emissions from drained peatlands in SE Asia. Delft Hydraulics report Q3943 (2006). Delft, The Netherlands: WL/Delft Hydraulics.

Hooijer A, Page S, Canadell JG, Silvius M, Kwadijk J, Wösten H, Jauhiainen J (2010) Current and future $\mathrm{CO}_{2}$ emissions from drained peatlands in Southeast Asia. Biogeosciences 7:1505-1514

Hooijer A, Page S, Jauhiainen J, Lee WA, Lu XX, Idris A, Anshari G (2012) Subsidence and carbon loss in drained tropical peatlands. Biogeosciences 9(3):1053-1071. doi:10.5194/bg-9-1053-2012

Hulme M, Mahony M (2010) Climate change: What do we know about the IPCC? Prog Phys Geog 34(5):705-718

Husen E, Salma S, Agus F (2013) Peat emission control by groundwater management and soil amendments: evidence from laboratory experiments. Mitig Adapt Strateg Glob Chang. doi:10.1007/s11027-013-9526-3, this issue

Husnain H, Agus F, Wigena IP, Dariah A, Marwanto S (2014) Peat $\mathrm{CO}_{2}$ emissions from several land use types in Indonesia. Mitig Adap Strateg Glob Chang. doi:10.1007/s11027-014-9550-y, this issue

Indonesia Forest Climate Alliance (IFCA) (2008) Reducing Emissions From Deforestation and Forest Degradation in Indonesia. IFCA Consolidation Report. Ministry of Forestry, Jakarta

IPCC (2014) 2013 Supplement to the 2006 IPCC Guidelines for National Greenhouse Gas Inventories: Wetlands. In: Hiraishi T, Krug T, Tanabe K, Srivastava N, Baasansuren J, Fukuda M, Troxler TG (eds). Methodological Guidance on Lands with Wet and Drained Soils, and Constructed Wetlands for Wastewater Treatment. IPCC, Switzerland

Janudianto, Mulyoutami E, Joshi L, Wardell DA, van Noordwijk M (2011) Recognizing traditional tree tenure as part of conservation and REDD + strategy: Feasibility study for a buffer zone between a wildlife reserve and the Lamandau river in Indonesia's REDD + Pilot Province. ASB Policy brief 22. ASB Partnership for the Tropical Forest Margins, Nairobi, Kenya

Jauhiainen J, Limin S, Silvennoinen H, Vasander H (2008) Carbon dioxide and methane fluxes in drained tropical peat before and after hydrological restoration. Ecology 89(12):3503-3514

Jupesta J, Boer R, Parayil G, Harayama Y, Yarime M, Oliveira JA, Subramanian SM (2011) Managing the transition to sustainability in an emerging economy: evaluating green growth policies in Indonesia. Environ Innov Soc Trans 1(2):187-191 
Kelly TJ, Baird AJ, Roucoux KH, Baker TR, Honorio Coronado EN, Ríos M, Lawson IT (2013) The high hydraulic conductivity of three wooded tropical peat swamps in northeast Peru: measurements and implications for hydrological function. Hydrol Process. doi:10.1002/hyp.9884

Kwon MJ, Haraguchi A, Kang H (2013) Long-term water regime differentiates changes in decomposition and microbial properties in tropical peat soils exposed to the short-term drought. Soil Biol Biochem 60:33-44

Mahmud M (2013) Assessment of atmospheric impacts of biomass open burning in Kalimantan, Borneo during 2004. Atmos Environ 78:242-249

Marwanto S, Agus F (2014) Is $\mathrm{CO}_{2}$ flux from oil palm plantations on peatland controlled by soil moisture and/or soil and air temperatures? Mitig Adap Strateg Glob Chang. doi:10.1007/s11027-013-9518-3, this issue

Maswar M 2011 Kajian cadangan karbon pada lahan gambut tropika yang didrainase untuk tanaman tahunan (Carbon stock in the drained tropical peat used for perennial plantation crops). $\mathrm{PhD}$ Dissertation, Bogor Agricultural University, Bogor, Indonesia

Maswar M, van Noordwijk M, Agus F (2013) Reducing emissions from peatlands (REPEAT). In: van Noordwijk M, Lusiana B, Leimona B, Dewi S, Wulandari D (eds) Negotiation-support toolkit for learning landscapes. World Agroforestry Centre (ICRAF) Southeast Asia Regional Program, Bogor, pp 148-152

Matthews, RB, van Noordwijk M, Lambin E, Meyfroidt P, Gupta J, Verchot L, Hegouac'h K, Veldkamp E (2014) Implementing REDD + (Reducing Emissions from Deforestation and Degradation): case study evidence on governance, evaluation and impacts. Mitig Adapt Strateg Clim Chang - This issue (MITI-D14-00055)

Medrilzam M, Dargusch P, Herbohn J, Smith C (2013) The socio-ecological drivers of forest degradation in part of the tropical peatlands of Central Kalimantan. Indonesia Forestry. doi:10.1093/forestry/cpt033

Miller C (2001) Hybrid management: boundary organizations, science policy, and environmental governance in the climate regime. SciTechnol HumVal 26(4):478-500

Mulia R, Widayati A, Suyanto S, Agung P, Zulkarnain MT (2014) Low carbon emission development strategies for Jambi, Indonesia: simulation and trade-off analysis using the FALLOW model. Mitig Adapt Strateg Glob Chang. doi:10.1007/s11027-013-9485-8, this issue

Murdiyarso D, Adiningsih ES (2007) Climate anomalies, Indonesian vegetation fires and terrestrial carbon emissions. Mitig Adapt Strateg Glob Chang 12(1):101-112

Murdiyarso D, Hergoualc'h K, Verchot LV (2010) Opportunities for reducing greenhouse gas emission in tropical peatlands. Proc Natl Acad Sci U S A 107(46):19655-19660

Murdiyarso D, Dewi S, Lawrence D, Seymour F (2011) Indonesia's forest moratorium. A stepping stone to better forest governance? Working paper 76, CIFOR, Bogor

Murdiyarso D, Kauffman JB, Verchot LV (2013) Climate change mitigation strategies should include tropical wetlands. Carbon Manag 4(5):491-499

Namirembe S, Leimona B, van Noordwijk M, Bernard F, Bacwayo KE (2014) Co-investment paradigms as alternatives to payments for tree-based ecosystem services. Curr Opin Environ Sust 6:89-97

Page SE, Rieley JO, Banks CJ (2011) Global and regional importance of the tropical peatland carbon pool. Glob Chang Biol 17:798-818

Ritung S, Wahyunto, Nugroho K et al (2011) Peta Lahan Gambut Indonesia Skala 1:250.000 (Indonesian peatland map at the scale 1:250,000). Indonesian Center for Agricultural Land Resources Research and Development, Bogor

Ritzema H, Limin S, Kusin K, Jauhiainen J, Wösten H (2014) Canal blocking strategies for hydrological restoration of degraded tropical peatlands in central Kalimantan, Indonesia. Catena 114:11-20

Shofiyati R, Las I, Agus F (2010) Indonesian soil database and predicted stock of soil carbon. In: Proceedings of international workshop on evaluation and sustainable management of soil carbon sequestration in Asian countries Bogor, Indonesia Sept. 28-29, 2010

Sofiyuddin M, Rahmanulloh A, Suyanto S (2012) Assessment of profitability of land Use systems in Tanjung Jabung barat district, Jambi province, Indonesia. Open J Forest 2:252-256

Tata HL, van Noordwijk M, Ruysschaert D, Mulia R, Rahayu S, Mulyoutami E, Widayati A, Ekadinata A, Zen R, Dorsayo A, Oktaviani R, Dewi S (2014) Will REDD + funding to reduce emissions from deforestation and (forest) degradation stop peat swamp conversion to oil palm in orangutan habitat in Tripa (Aceh, Sumatra, Indonesia)? Mitig Adapt Strateg Glob Chang. doi:10.1007/s11027-013-9524-5, this issue

Van Eijk P, Kumar R (2009) Bio-rights in theory and practice. A financing mechanism for linking poverty alleviation and environmental conservation. Wetlands International, Wageningen

Van Noordwijk M (2014) Avoided land degradation and enhanced soil C storage: is there a role for carbon markets? SCOPE Review of multiple benefits of soil organic carbon. CAB-International, Wallingford

Van Noordwijk M, Khasanah N, Dewi S (2013) Biofuel emission reduction estimator scheme (BERES): land-use history, production systems and technical emission factors. In: van Noordwijk M, Lusiana B, Leimona B, Dewi S, Wulandari D (eds) Negotiation-support toolkit for learning landscapes. World Agroforestry Centre (ICRAF) Southeast Asia Regional Program, Bogor, pp 157-162 
Van Noordwijk M, Agus F, Dewi S, Purnomo H (2014) Reducing emissions from land use in Indonesia: motivation, policy instruments and expected funding streams. Mitig Adapt Strateg Glob Chang. doi:10. 1007/s11027-013-9502-y, This issue

Yamamoto Y, Takeuchi K, Köhlin G (2013) What Factors Promote Peatland Fire Prevention?: Evidence from Central Kalimantan, Indonesia (No. 1312). Graduate School of Economics, Kobe University.

Zoomers A (2010) Globalisation and the foreignisation of space: seven processes driving the current global land grab. J Peasant Stu 37(2):429-447 